\title{
Tree density and site quality influence on Pinus halepensis Mill. reproductive characteristics after large fires
}

\author{
Daniel MoYA $^{a *}$, Josep M. ESPELTA ${ }^{\mathrm{b}}$, Iraima VERKAIK ${ }^{\mathrm{b}}$, Francisco LóPEZ-SERRANO $^{\mathrm{a}}$, \\ Jorge DE LAS HERAS ${ }^{\mathrm{a}}$ \\ ${ }^{a}$ Escuela Técnica Superior de Ingenieros Agrónomos de Albacete, Universidad de Castilla-La Mancha, \\ Campus Universitario s/n. 02071 Albacete, Spain \\ ${ }^{\mathrm{b}}$ CREAF (Centre for Ecological Research and Forestry Applications), Universidad Autonoma de Barcelona 08193 Bellaterra, Spain
}

(Received 29 November 2006; accepted 24 January 2007)

\begin{abstract}
In Spain, many Pinus halepensis Mill. forests have been seriously affected by significant forest fires in the past decade, in 1994 alone, more than 100000 ha were burned in Eastern Spain. In order to study the reproductive characteristics of $P$. halepensis after forest fires, six locations were selected in four areas affected by serious fires in the summer of 1994, and the following different precipitation zones were studied: dry-subhumid, dry and semi-arid. Ten years after the fires, data relevant to the production of pine cones: serotinous (grey), mature (brown), immature (green) and opened cones, was collected from areas with natural post-fire regeneration. Various cone and seed characteristics, such as pine cone seed number and weight, and germination percentage, were measured. The results showed greater production of cones and strobili in high-density sites. The biggest cone sizes (volume) and seed number per cone were related to site quality (dry-subhumid precipitation zone). Also, viability and germination percentages were higher with better site quality, with significant differences in values for serotinous and non-serotinous cones. Despite these differences, the canopy seed bank was large enough to ensure regeneration in this area for this age stand.
\end{abstract}

Pinus halepensis / serotiny / canopy seed bank / natural regeneration

Résumé - Influence de la densité du peuplement et de la fertilité de la station sur la dynamique de reproduction de Pinus halepensis Mill., dix ans après d'importants incendies. En Espagne, dans les dix dernières années, de nombreuses forêts de Pin d'Alep ont été gravement touchées par d'importants feux de forêt. Rien qu'en 1994, plus de 100000 ha ont brûlé dans l'est de l'Espagne. Dans le cadre d'une étude de la dynamique de la reproduction du Pin d'Alep après incendie, six sites, situés dans des zones de feux de forêt survenus lors de l'été 1994, ont été observés. Ces sites présentent des niveaux de précipitations différents : sec à sub-humide, sec et semi-aride. Dix ans après incendie, des données concernant la production de cônes de pin : sérotineux (gris), mûrs (marrons), immatures (vert) et cônes ouverts, ont été collectées dans des zones de régénération naturelle. Diverses caractéristiques des cônes et des graines ont été relevées : nombre et poids des cônes et des graines, taux de germination. Les résultats révèlent une production importante de cônes et de strobiles dans les sites à forte densité de pin. Le volume des cônes et le nombre de graines par cône étaient liés à la fertilité de la station (zone sèche à sub-humide). Les taux de viabilité et de germination étaient aussi plus importants dans les zones présentant le plus de précipitations et des écarts significatifs ont été observés entre les valeurs de cônes sérotineux et non sérotineux. Malgré ces différences, les banques de graines dans les peuplements étaient suffisamment importantes pour assurer la régénération du pin dans cette zone.

Pinus halepensis / sérotine / banque de graines de la canopée / régénération naturelle

\section{INTRODUCTION}

The Mediterranean Basin is an intensely anthropized area where forest fires are associated with the landscape. This is one of the principal factors determining the mosaic-like character of the Mediterranean landscape [1,30,32,35]. Recurrent fires can prompt adaptations and influence forest development, especially in Pinus halepensis Mill. [4,30]. Aleppo pine is a widely distributed conifer in the Mediterranean Basin which is well-known as an obligatory seeder and for its ability to grow in difficult environmental conditions [46] such as burned sites and open spaces where no competing species grow [10]. When a fire occurs, the adult plants die and their regeneration is entirely dependent on the canopy-stored seed bank. Massive

* Corresponding author: Daniel.Moya@uclm.es germination, triggered by fire-related factors such as heat or smoke $[14,26]$ and influenced by the first winter rains after a fire [31], can result in dense pine stands developing throughout the burned area [21].

In areas with frequently recurring fires, early flowering is necessary for successful post-fire colonization, and there are several studies that have recorded flowering in five-year-old stands $[7,41,42]$. Also it has been suggested that forest age, tree density, environmental conditions and site characteristics contribute to variations in the number of cones produced [21, 43].

Serotiny is common in pine species growing in ecosystems affected by fires $[2,45]$. Seeds stored in serotinous cones are released after a fire and take advantage of post-fire conditions to germinate their seeds and establish seedlings [23,25]. 


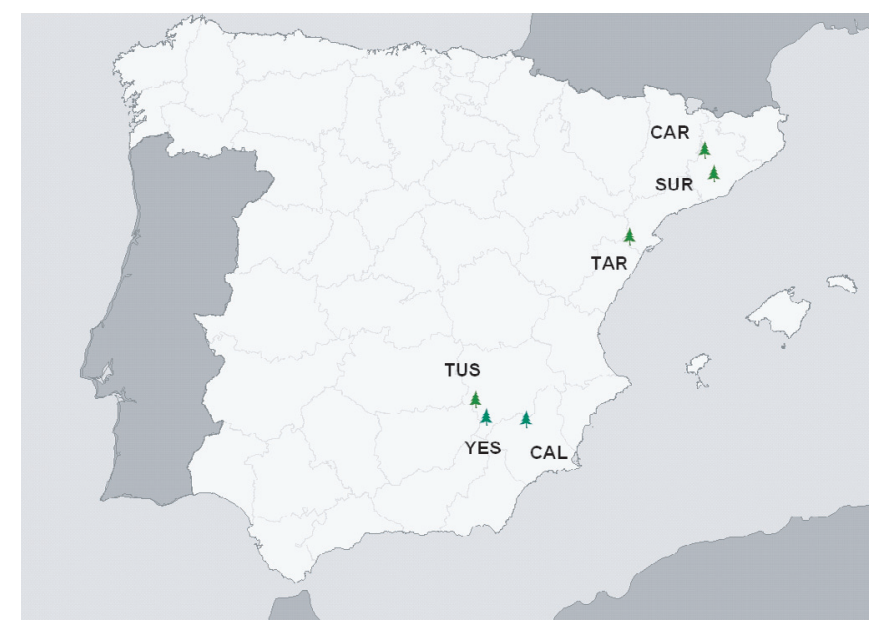

Figure 1. Sites location in the Iberian Peninsula

In Aleppo pine, a dual strategy with two different types of seeds for different scenarios has been described $[28,29]$. The serotiny level of pine stands must be taken into consideration because research reports that serotinous and non-serotinous cones appear simultaneously, with their proportion related to several factors, including size, age and tree density [24]. In one strategy, seeds germinate from non-serotinous cones under warm and dry weather conditions, and in the other, they develop from serotinous cones that release their seeds after fire because serotinous cones open at high temperatures and low relative humidity. However, many of these serotinous cones may also open given certain special conditions such as dry spell or dry winds [23]. Germination can be affected by many factors such as high temperature [17], ash presence [33], nitrogen content [5] and litter cover, among others. Furthermore, germination responses show differences depending on whether seeds are from serotinous or non-serotinous cones. Pine provenance must also be regarded as an important factor in determining germination [9].

The increase in forest fires in the Iberian Peninsula in the past decade has increased the distribution of $P$. halepensis, especially in Eastern areas, as in other areas of the Mediterranean Basin affected by recurrent forest fires [22, 27].

Differences in cone production, growth and foliate nutrients $[20,34]$ have been described for different fires and different locations. However, there is not sufficient knowledge concerning differences in cone production depending on site quality or tree density due to the difficulty in finding similar regeneration scenarios.

The natural and artificial extension of P. halepensis forests and the increase in the number of fires and burned areas in Spain makes it necessary to know what differences exist in the main reproductive characteristics such as canopy seed bank storage, the number of immature cones and germination capability. This information provides knowledge on the current status of different reproduction responses observed according to density and site quality. Also, these results give an idea of the possible future development of pine stands. The reproduc- tive characteristics selected were based on the measurement of variables commonly used in similar studies: the number of strobili and cone types [24]; cone weight and volume and seed number per cone [44]; and the number of sound seeds, viability and germination rates $[12,43]$. If a new fire occurred before the tree reached the reproductive phase, post-fire natural regeneration might be deficient $[10,43]$ which produces important environmental impacts as risk of soil loss, loss of biodiversity, loss of carbon sink, etc. This information could be very useful for foresters when making management decisions, for example in applying silvicultural treatments in the early stages of regrowth [13].

In 1994, four serious forest fires occurred in Eastern Spain, in which 100000 ha were burned. Each of these forests primarily affected mature Aleppo pine trees and, as shown in previous studies, monospecific Aleppo pine forests usually return to their original state after a fire [6]. The present paper conducts a study of natural Aleppo pine regeneration 10 years after a fire event (in areas of similar age and environmental conditions), in order to evaluate cone and seed characteristics, as well as the canopy-stored seed bank depending on differences in climate and tree density.

\section{MATERIALS AND METHODS}

\subsection{Study Site}

The study was carried out at six sites located in four different areas affected by large forest fires in the summer of 1994 and distributed from $\mathrm{N}$ to $\mathrm{S}$ in Eastern Spain (Fig. 1). Two of these fires occurred in the provinces of Barcelona and Tarragona (NE Spain), where 50000 ha and 12500 ha were burned, respectively, and the other two in the provinces of Albacete and Murcia (SE Spain), where 14000 and 30000 ha were burned. In all of these areas, natural regeneration resulted in high-density stands of Aleppo pine (90\% of the total burned surface two years after the fire), although final density varied $[21,47]$. There were several similarities in all six sites: coverage by mature Pinus halepensis forests; stand age (10 years old); years since the two most recent fires (in 1994 and over 40 years without a forest fire, respectively), as demonstrated by old aerial photographs and land use maps.

The main soil characteristics were similar in all areas studied: carbonated substratum, $\mathrm{pH}$ values between 8.5 and 8.7 and low slope $(<5 \%)$. Climate and resource availability (with water shown to be the most significant) were considered the principal factors influencing dependent variables. In addiction, conifers have developed adaptive strategies for drought $[3,19]$. Therefore, site quality (which includes all of the above parameters) is considered the main factor influencing variations in stand development variables.

\subsection{Experimental design}

Six sites were selected in areas affected by significant fires in the summer of 1994. The sites were located in Cardona (CAR), Súria (SUR), Tarragona (TAR), Yeste (YES) and Calasparra (CAL). They were distributed along the Eastern Iberian Peninsula (Fig. 1). Growth and reproduction characteristics were studied in 24 plots located 


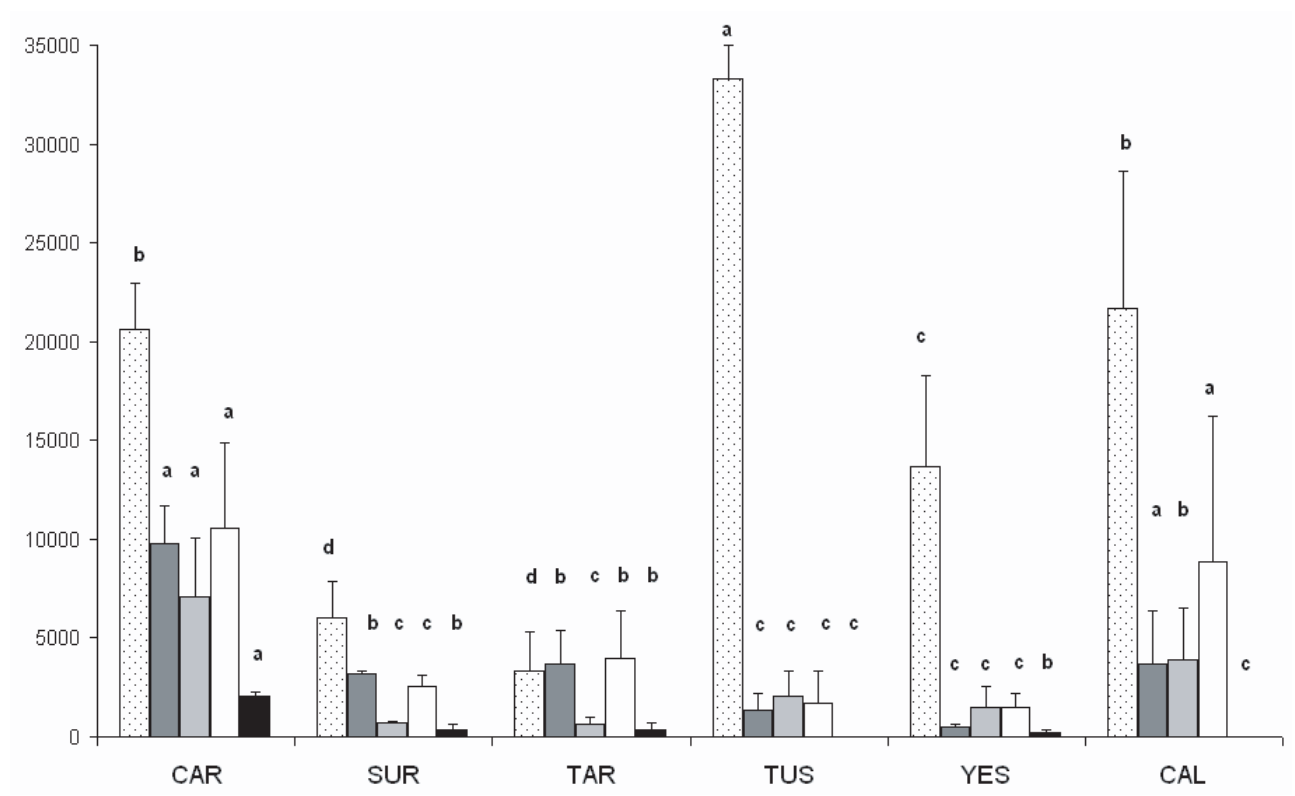

Figure 2. Cone production ( $\mathrm{X}$ axis: site; Y axis: number of cones per Ha). Pointed bar: strobili (first year cones); dark grey bar: immature cones (green); soft grey bar: mature cones (brown); white bar: serotinous cones (grey); black bar: opened cones.

Table I. Summary characteristics of the study sites. NP: Number of plots; COORD: Geographical coordinates (WGS 84 datum); BS: total burned surface (ha) in 1994; D: Density (trees ha ${ }^{-1} \pm \mathrm{SE}$ ); A: Altitude (m); P: average annual rainfall (mm \pm SE); T: annual temperature $\left({ }^{\circ} \mathrm{C} \pm \mathrm{SE}\right)$; CL: ombroclimate (Thornwaite index).

\begin{tabular}{lcccccccc}
\hline Site & NP & COORD & BS & D & A & P & T & CL \\
\hline CAR & 3 & $41^{\circ} 55^{\prime} \mathrm{N} ; 1^{\circ} 41^{\prime} \mathrm{W}$ & 25000 & $53221 \pm 1427$ & 530 & 798 & 12.0 & Dry-sub humid \\
SUR & 3 & $41^{\circ} 49^{\prime} \mathrm{N} ; 1^{\circ} 42^{\prime} \mathrm{W}$ & 25000 & $32722 \pm 2902$ & 510 & 756 & 11.5 & Dry-sub humid \\
TAR & 7 & $40^{\circ} 46^{\prime} \mathrm{N} ; 0^{\circ} 17^{\prime} \mathrm{W}$ & 12500 & $25187 \pm 1713$ & 350 & 659 & 13.6 & Dry-sub humid \\
TUS & 5 & $38^{\circ} 22^{\prime} \mathrm{N} ; 2^{\circ} 24^{\prime} \mathrm{W}$ & 14000 & $61145 \pm 389$ & 1010 & 600 & 13.0 & Dry \\
YES & 3 & $38^{\circ} 20^{\prime} \mathrm{N} ; 2^{\circ} 20^{\prime} \mathrm{W}$ & 14000 & $7089 \pm 468$ & 900 & 530 & 12.7 & Dry \\
CAL & 3 & $38^{\circ} 16^{\prime} \mathrm{N} ; 1^{\circ} 38^{\prime} \mathrm{W}$ & 30000 & $62669 \pm 956$ & 325 & 290 & 16.5 & Semiarid \\
\hline
\end{tabular}

within the sites. Each site represented a different stand tree density and climate conditions (Tab. I). They were located randomly within the sites and were circular in design $\left(r=10 \mathrm{~m} ; 350 \mathrm{~m}^{2}\right)$. Each plot consisted of trees from natural, post-fire regeneration over an ecologically homogeneous area. In each plot 20-25 trees were randomly selected to be monitored and measured throughout 2004.

Local tree density was estimated for each plot by counting the total number of trees. Site quality was quantified by measuring the dominant height in each site (average height of the 100 tallest trees per ha). In this study, due to the small plot area, we selected the average of the two highest trees. Dominant height is strongly correlated to annual rainfall in these sites (Logarithm-X regression, $p<0.01$, correlation $=0.6271$ and $R^{2}=39.95 \%$ ), which demostrates that it is an accurate indicator of site quality. Sites were grouped, according to latitude and average annual rainfall, as northern dry sub-humid (CAR, SUR and TAR), southern dry (TUS and YES) and southern semi-arid (CAL) precipitation zones [36]. So the study compared six different values for tree density and three for site quality distributed along Eastern Spain.

\subsection{Measurement of reproductive characteristics}

Fertilized cones were counted and classified based on appareance and age (counting whorls over the insertion point) as: green or im- mature (less than two years old), brown or mature (two to three-yearold cones), grey or serotinous (four years old or older) and opened cones. This classification is based on previous studies [24, 44]. For the purpose of this study serotiny is regarded as the proportion of the total number of cones produced during a tree's lifetime which remain closed after maturation.

The total number of cones produced was regarded as the number of mature, serotinous and opened cones. The reproductive characteristics studied are based on records from mature and serotinous cones.

Reproductive characteristic measurements were taken at the selected sites, with the exception of viability and germination percentages at the TUS site. For this purpose six mature and serotinous cones were collected from the lower, external part of the tree crown $[40,44]$ outside each experimental plot. Once in the laboratory, the volume of each cone was measured by immersing cones in water in a test tube (accuracy to $0.01 \mathrm{~mm}^{3}$ ). Sample cones were kept in boiling water for one minute and then oven-dried at $45^{\circ} \mathrm{C}$ for $48 \mathrm{~h}$ in order to open them. Seeds were manually extracted and counted in each cone to obtain the number of seeds per cone (separated for cone type and study site). Average cone weight was calculated by weighing cones in a balance (accuracy to $0.01 \pm 0.01 \mathrm{~g}$ ).

The percentage of sound and unsound seeds per cone was calculated by a cutting test, wherein a sample of 50 seeds were cut and observed. Those which were morphologically mature (germ and reserve 
tissues look healthy) were classified as sound and the others as unsound (empty or unhealthy appearance) [12]. Viability percentage was calculated applying the Tetrazolium method [11] to the sound seeds. Four replicates of 25 seeds each were randomly selected for each site and cone type (mature or serotinous), and placed in petri dishes. The seeds were continuously watered to maintain the required humidity level. The germinators were kept in a germination chamber at a constant temperature of $20 \pm 0.5^{\circ} \mathrm{C}$ with a 14 -h photoperiod [43]. Germination (seeds with a geotropic radicle longer than $2 \mathrm{~mm}$ ) was recorded every 2-3 days for 35 days. Germinated seeds were recorded and subsequently removed [9].

After the germination period, non-germinated seeds were cut open to establish the number of sound and unsound seeds (unsound seeds were not used to calculate the germination percentage). The results were expressed as the percentage of sound seeds (mean number of sound seeds out of the total number of cut seeds), viability percentage (mean number of coloured seeds out of the total treated seeds) and germination percentage (percentage of sound germinated seeds in the petri dishes).

Canopy seed bank was defined as the number of viable seeds per hectare and was estimated separately for seeds from mature and serotinous cones from each plot [24]. It was calculated as the product of: the average number of cones per hectare, the average number of seeds per cone and the average percentage of viable seeds. The number of seeds per cone was defined as the average number of sound seeds contained in each cone and was calculated by multiplying the average number of seeds per cone and the percentage of sound seeds, depending on the cone type for each site.

To estimate the canopy seed bank storage, two classes were established: SSB: serotinous seed bank density (considering seeds from serotinous cones) and MSB: mature seed bank density (seeds from mature cones). Canopy seed bank (CSB) store was obtained by adding the values for these two classes. The results for canopy seed bank are only valid for the current year (2004) because the next year, cones will have undergone changes: immature cones will ripen (and therefore be included with the mature cones) and mature cones could either become serotinous or opened cones. Serotinous cones could also open or remain closed.

\subsection{Statistical analysis}

For all statistical analyses data were transformed using log or $\sqrt{\operatorname{arcsine}}$ transformations to achieve normality assumptions and homoscedasticity. The data shown in the tables and figures have not been transformed, standard errors $( \pm$ SE) are included. Simple and Multiple ANOVA were used to test differences, and Fisher's Least Significant Difference (LSD) procedure was used to compare mean values. The relationship between dependent variables and factors was tested using the General Linear Model (GLM) expressed as an equation containing the sum of the independent variable values, plus a term for all unknown factors (error term). In cases where there was a relationship between two variables, only a simple regression test was performed. The Kruskal-Wallis test was used to check median significant differences between independent variables. All statistical analyses were conducted using a critical $p$-value of $\leqslant 0.05$.

PCA was carried out using tree density, number of seeds per cone, site quality, volume and weight per cone, viability, germination and sound seed percentage as variables. The purpose of the analysis was to obtain relationships for the parameters studied. In this case, the first two components account for $56.41 \%$ of the variability in the original data.

\section{RESULTS}

\subsection{Cone production}

Strobili production was higher in TUS (33295.4 \pm 1702.7 strobili $\mathrm{ha}^{-1}$ ), although in general the annual crop was very low for this site (Fig. 2). The number of serotinous cones was significantly higher in CAR and CAL. For other cone types the highest cone production was recorded in CAR $\left(9779.3 \pm 1902.18\right.$ immature cones ha ${ }^{-1}, 7086.7 \pm 2980$ mature cones $\mathrm{ha}^{-1}$ and $10571 \pm 4307$ serotinous cones ha ${ }^{-1}$ ) and the same pattern was observed in open cones $(2088 \pm$ 208 opened cones $\mathrm{ha}^{-1}$ ). It is also significant that TUS and CAL did not produce any open cones.

An analysis of factors related to cone production revealed a positive correlation between total cone production and pine tree density $\left(p<0.01 ; F^{2}=51.61\right)$. MANOVA showed a significant relationship between tree density and immature $(p<0.01, F=30.19)$ and serotinous $(p<0.01, F=2916)$ cones. Also a significant correlation was found between site quality ( $p<0.01, F=11.52)$ and the number of open cones per hectare $\left(p<0.01 ; F^{2}=32.60\right)$.

\subsection{Cone and seed characteristics}

Mean values and significant differences for each site are shown in Table II and the interaction from GLM can be seen in Table III.

Cone volume and the weight of mature cones did not present significant differences at different sites. However, CAR, SUR and TAR presented higher numbers of seeds per mature cone.

Average cone weight did not vary significantly at different sites, as is the case for mature cones, but CAR, SUR and TAR showed significantly higher values for serotinous cones.

Average cone volume and weight did not present differences for cone type (mature or serotinous) and non-interactive factors were recorded. Furthermore, a significant interaction with respect to the number of seeds per cone was found, with the significant factors being cone type and tree density

Significant differences were found in the percentages of sound seeds per cone (Fig. 3). The highest values were reached in YES $(87.78 \pm 2.78$ and $87.60 \pm 2.41 \%$ for mature and serotinous cones respectively) and the lowest values were in CAL (51.67 $\pm 25.87 \%$ for serotinous cones) and TAR (69.12 \pm $5.68 \%$ for mature cones).

In general, the results showed a high germination percentage in the sites studied (more than $74 \%$, with the exception of CAL) and viability percentage values fluctuated from $95.53 \pm$ $1.45 \%$ and $93.17 \pm 0.71 \%$ in SUR to $59.72 \pm 12.75 \%$ and $68.33 \pm 0.50 \%$ in CAL (for seeds from mature and serotinous cones, respectively) (Fig. 4). 
Table II. Cone Characteristics for serotinous and mature types. V: mean cone volume $\left(\mathrm{mm}^{3}\right) \pm \mathrm{SE}$; SN: mean number of seeds per cone \pm SE; $\mathrm{W}$ : mean cone weight $(\mathrm{g}) \pm \mathrm{SE}$. Small letters mean significant differences (LSD method) among sites at $p<0.05$.

\begin{tabular}{|c|c|c|c|c|c|c|}
\hline \multirow{2}{*}{ Site } & \multicolumn{3}{|c|}{ Serotinous cones } & \multicolumn{3}{|c|}{ Mature cones } \\
\hline & $\mathrm{V}$ & $\mathrm{SN}$ & $\mathrm{W}$ & $\mathrm{V}$ & $\mathrm{SN}$ & $\mathrm{W}$ \\
\hline$\overline{\text { CAR }}$ & $16.03 \pm 1.25^{\mathrm{a}}$ & $84.53 \pm 4.94^{\mathrm{a}}$ & $16.50 \pm 0.81^{\mathrm{a}}$ & $17.19 \pm 1.13^{\mathrm{b}}$ & $101.44 \pm 8.03^{\mathrm{a}}$ & $14.61 \pm 0.33^{\mathrm{a}}$ \\
\hline SUR & $11.80 \pm 0.47^{\mathrm{b}}$ & $75.02 \pm 4.97^{\mathrm{a}}$ & $15.81 \pm 0.37^{\mathrm{b}}$ & $9.75 \pm 0.91^{\mathrm{c}}$ & $94.72 \pm 2.23^{\mathrm{a}}$ & $10.00 \pm 0.58^{b}$ \\
\hline TAR & $17.99 \pm 1.53^{\mathrm{a}}$ & $92.66 \pm 3.73^{\mathrm{a}}$ & $13.48 \pm 1.35^{\mathrm{a}}$ & $19.02 \pm 1.99^{\mathrm{a}}$ & $109.64 \pm 6.04^{\mathrm{a}}$ & $10.57 \pm 1.51^{\mathrm{a}}$ \\
\hline TUS & $16.72 \pm 2.38^{a}$ & $58.50 \pm 5.50^{\mathrm{a}}$ & $15.47 \pm 1.84^{\mathrm{c}}$ & $15.61 \pm 1.45^{\mathrm{b}}$ & $50.50 \pm 18.50^{\mathrm{a}}$ & $14.64 \pm 2.41^{\mathrm{d}}$ \\
\hline YES & $11.89 \pm 1.52^{\mathrm{b}}$ & $72.00 \pm 8.62^{\mathrm{a}}$ & $14.25 \pm 0.95^{\mathrm{b}}$ & $21.82 \pm 6.55^{\mathrm{a}}$ & $74.78 \pm 3.13^{\mathrm{a}}$ & $14.51 \pm 3.25^{\mathrm{c}}$ \\
\hline CAL & $8.60 \pm 2.61^{\mathrm{c}}$ & $48.28 \pm 7.80^{\mathrm{a}}$ & $11.35 \pm 4.71^{\mathrm{c}}$ & $9.42 \pm 1.47^{\mathrm{c}}$ & $67.89 \pm 19.07^{\mathrm{a}}$ & $12.71 \pm 1.82^{\mathrm{d}}$ \\
\hline
\end{tabular}

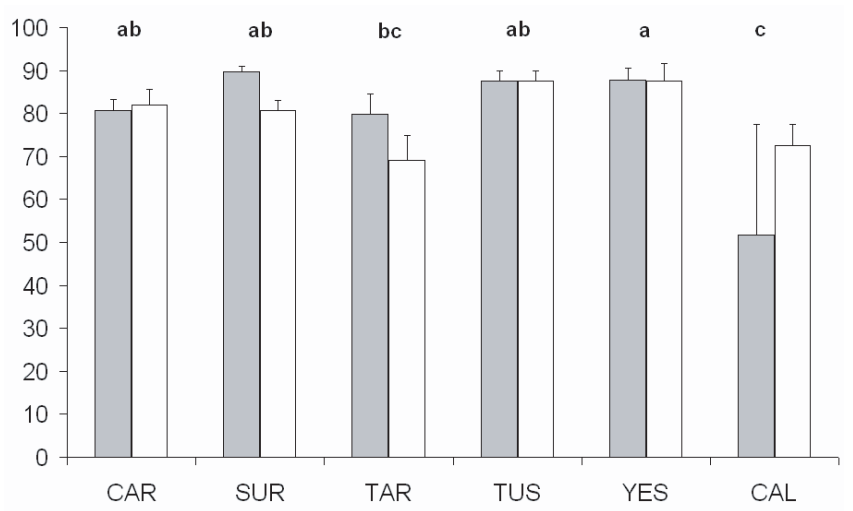

Figure 3. Mean percentage of sound seeds per cone ( $\mathrm{X}$ axis: site; $\mathrm{Y}$ axis: percentages). White bar: mature cones; grey bar: serotinous cones. Small letters mean significant differences (LSD method) among sites at $p<0.05$.

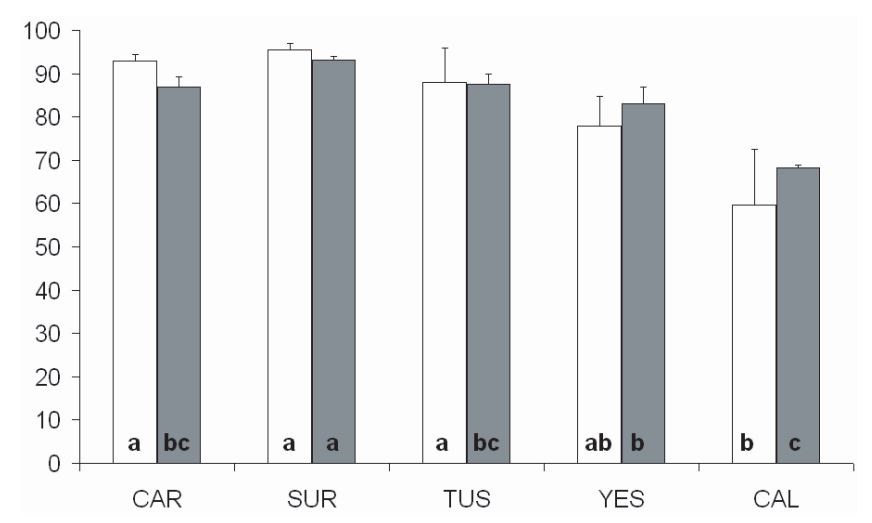

Figure 4. Seed viability from tetrazolium method ( $\mathrm{X}$ axis: site; $\mathrm{Y}$ axis: percentage). White bar: mature cones; grey bar: serotinous cones. Small letters mean significant differences (LSD method) among sites at $p<0.05$.

Average germination percentage values (Fig. 5) were significantly higher in the more northern sites (CAR and SUR), although values were exceptionally high in TUS (almost $100 \%)$. Significantly low values were found in CAL (65.00 \pm $3.33 \%$ and $51.94 \pm 17.71 \%$ for seeds from serotinous and mature cones, respectively). The GLM showed that viability experienced significant interactions by the site quality factor, so
Table III. GLM was applied to reproductive characteristics (RCh). GLM provides regression analysis and analysis of variance for one dependent variable (each $\mathrm{RCh}$ variable) by one or more independent factors. Categorical variables are accepted in this tool so dummy variables are not manipulated. Significant models are bold written and significant factor (for the analyzed variables) are italic written. * Indicates significant models and interactive factors $(p<0,05)$.

\begin{tabular}{|c|c|c|c|c|}
\hline $\mathrm{RCh}$ & $p$-value & $R^{2}$ & Factor & $p$-value \\
\hline Volume & 0.09 & 16.51 & & \\
\hline Weight & 0.21 & 11.80 & & \\
\hline Full seed & 0.25 & 10.79 & & \\
\hline \multirow[t]{2}{*}{ Germination } & 0.35 & 13.03 & & \\
\hline & & & Cone type & 0.85 \\
\hline \multirow[t]{3}{*}{ Viability } & 0.03* & 31.73 & Density & 0.36 \\
\hline & & & Site quality & $<0.01 *$ \\
\hline & & & Cone type & $0.04 *$ \\
\hline \multirow[t]{2}{*}{ Seed number } & $<0.01 *$ & 28.79 & Density & $0.08^{*}$ \\
\hline & & & Site quality & $<0.01 *$ \\
\hline
\end{tabular}

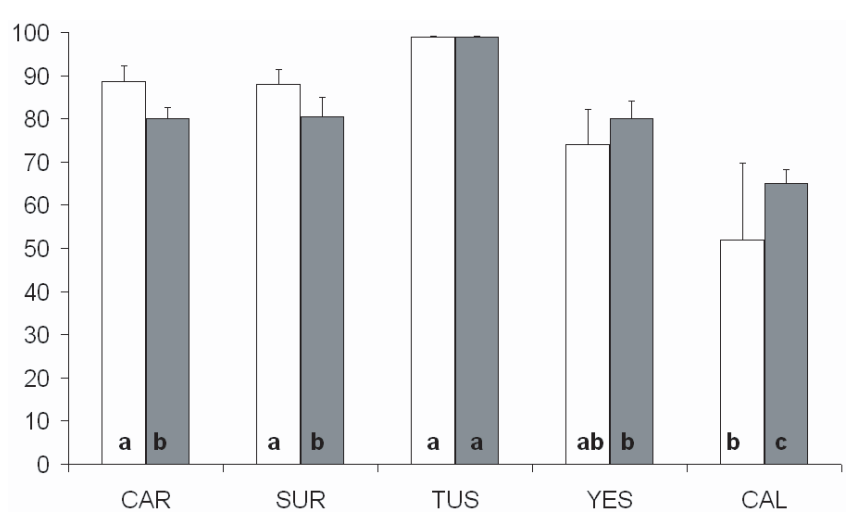

Figure 5. Seed germination ( $\mathrm{X}$ axis: site; $\mathrm{Y}$ axis: percentage). White bar: mature cones; grey bar: serotinous cones. Small letters mean significant differences (LSD method) among sites at $p<0.05$.

simple regression was applied. The best correlation was obtained using an $\mathrm{X}$-inverse model $\left(p<0.01, R^{2}=62.17\right.$, $F=41.08 ; \mathrm{CC}=-0.79)$.

PCA analysis (Fig. 6) showed the correlation between factors and variables. It is clear that the number of sound seeds was correlated with tree density. Germination percentage 
Table IV. Aleppo pine cone crop (serotinous and mature) in the study sites and canopy seed bank in summer 2004. SC: serotinous cones per ha \pm SE; MC: mature cones per ha \pm SE; AC: annual cone crop per ha \pm SE; SSB: serotiny seed bank per ha \pm SE. MSB: mature seed bank per ha \pm SE.; CSB: canopy seed bank per ha \pm SE. Small letters mean significant differences (LSD method) among sites at $p<0.05$.

\begin{tabular}{lcccccc}
\hline Site & SC & MC & AC & SSB & MSB & CSB \\
\hline CAR & $10500 \pm 4000$ & $7000 \pm 3000$ & $17500 \pm 6000^{\mathrm{a}}$ & $375000 \pm 225000$ & $550000 \pm 250000$ & $925000 \pm 450000^{\mathrm{a}}$ \\
SUR & $2500 \pm 575$ & $700 \pm 100$ & $3200 \pm 350^{\mathrm{c}}$ & $160000 \pm 40000$ & $15000 \pm 15000$ & $175000 \pm 30000^{\mathrm{c}}$ \\
TAR & $4000 \pm 2500$ & $600 \pm 375$ & $4600 \pm 550^{\mathrm{c}}$ & - & - & - \\
TUS & $1700 \pm 150$ & $2000 \pm 1275$ & $3700 \pm 1250^{\mathrm{c}}$ & $180000 \pm 18000$ & $670000 \pm 575000$ & $850000 \pm 750000^{\mathrm{b}}$ \\
YES & $1500 \pm 700$ & $1500 \pm 1000$ & $3000 \pm 1000^{\mathrm{c}}$ & $75000 \pm 35000$ & $50000 \pm 35000$ & $125000 \pm 55000^{\mathrm{d}}$ \\
CAL & $9000 \pm 7500$ & $4000 \pm 2500$ & $13000 \pm 5000^{\mathrm{b}}$ & $270000 \pm 200000$ & $90000 \pm 45000$ & $360000 \pm 185000^{\mathrm{c}}$ \\
\hline
\end{tabular}

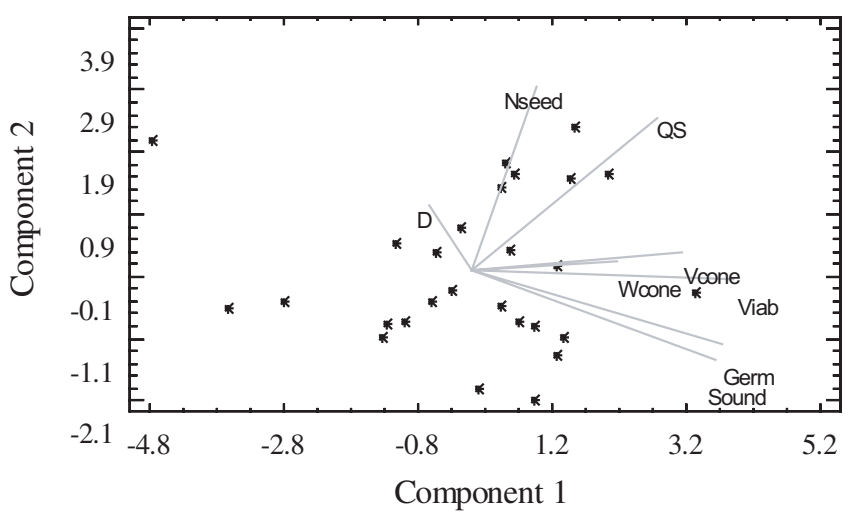

Figure 6. PCA analysis. D: density; Nseed: number of seeds per cone; QS: site quality; Vcone: volume per cone; Wcone: weight per cone; Viab: viability percentage; Germ: germination percentage; Sound: sound seeds percentage. The first component accounts for $37.80 \%$ and second component accounts for $18.61 \%$, accumulating $56.41 \%$ of variability in the original data.

appears similar to the number of sound seeds. A three-way correlation grouped viability percentage, volume and weight cone which could be indicative of cone vigor.

\subsection{Canopy seed bank}

As can be seen in Table IV, the highest annual cone yield values were obtained in CAR $\left(17500 \pm 3000\right.$ cones ha $\left.{ }^{-1}\right)$, whereas the lowest values were obtained in YES (3000 \pm 1000 cones ha ${ }^{-1}$ ), similar results were found for the canopystored seed bank.

\section{DISCUSSION}

For Pinus halepensis Mill., spatial dynamics are partially predictable [30], e.g. synchronized germination explains the typical coevality of post-fire forests [37]. This is the premise for this study, which is based on four serious fires that occurred in 1994 in areas throughout Eastern Spain. Locations were covered by dense Aleppo pine stands 10 years after fires. In this particular case, seed dispersal occurred by means of pyriscent mechanisms promoted by high temperatures reached in wildfires, which led to the establishment of even-aged populations comprised of large numbers of pine trees [29]. Postfire germination can be influenced by several factors such as ash, charcoal and heat [34]. In this study two principal factors have been considered as sources of diversity in the reproductive characteristics of pine populations: tree density and site quality (influence of climate). These factors were studied summarizing them into the term "site".

In general, low densities are conducive to early flowering, a higher number of reproductive trees and higher cone production for individual trees [24, 40]. We might draw attention to CAL site, which had the lowest site quality and highest tree density ( more adverse conditions). Low densities ensure greater availability of water and nutrients and higher light intensity, which is conducive to higher cone production per tree $[21,41,46]$. In general it has been proven that cone production in high density locations occurs later than in locations with isolated pine trees [32], so density could be an important factor affecting reproductive characteristics. Also, many studies demonstrate that the presence of serotinous cones prior to fire determines post-fire regeneration in Aleppo pine [29] and other serotinous species such as $P$. contorta [39].

High production of serotinous cones is a response to disturbance (recurrent fires, drought), which has been described for Aleppo pine in the Mediterranean Basin [33,41]. In this study, cone production was positively linked to site quality and tree density. This was due to the young age of these forests, since the higher number of trees with low individual cone production induce a large yield, although small numbers of trees with high individual cone production could produce similar yield. Similar situations have been identified in other studies $[20,47]$. In the case of open cones there was a positive correlation with site quality (climate), which favoured taller trees. Although tree height has been demonstrated to be related with cone opening, the proportion of serotinous cones could be a response to other factors such as fire recurrence as well as site quality.

The average seed per cone values obtained are similar to those found in other pine tree populations in Israel $[24,28]$, SE Spain [40] and Greece [12]. In this study the average number of seeds per cone showed differences depending on site quality, tree density and cone type. Better site quality (CAR) exhibited the highest values as seen in high quality but low density sites (such as TAR). The lowest tree density and low 
quality site (YES) produced almost the same number of seeds as better site quality, high tree density site. This result explains the adverse influence of poor site quality can be compensated by low intraspecific competence.

Therefore, we can conclude that cone size (volume) and seed number per cone depend on the availability of resources, with water and tree height as the limiting factors. Background studies demonstrated the same conclusions $[21,44]$ in other Mediterranean areas. Thus, site quality seems to play an important role in seed production, which is linked to tree density, and in turn influences seed number [13].

Another result of the study showed that not all seeds were viable. In this respect, it was important to note a significant decrease in germination and viability in the southern sites (YES and CAL), since site quality was shown to be a significant factor negatively affecting viability. Viable seed number increases when availability of water and nutrients is adequate $[8,18]$ and decreases when pollen supply is insufficient [44]. Pollen availability in TUS (where some old trees were left standing after fire) could explain the high values obtained for a dry ombroclimate.

The germination percentages obtained (except for CAL, which exhibited very low values) were similar to those recorded in other studies carried out in the Mediterranean Basin $[5,12,18,20]$. Differences in germination percentages for seeds collected from serotinous and nonserotinous cones have also been noted in other studies [15, 24]. In this study the significant differences in viability values (Tetrazolium method) between seeds from each cone type were also recorded.

Since tree density influences the variables studied, we can deduce that Aleppo pine stands resulting from post-fire regeneration are affected by early silvicultural treatments such as thinning, which can increase seed production and individual cone production. Reducing tree density leads to a greater increases in diameter and height, although it could also result in a loss of seeds from the canopy seed bank [21]. Therefore, another question is: what is the best stand age for carrying out treatments to prevent seed loss and increase the total amount of annual cone yield in order to store a larger canopy seed bank? This seed bank indicates the number of seeds available once they are liberated by fire to result in natural, post-fire regeneration $[21,23,24]$. This is an important factor for postfire persistence; other studies have estimated that production of about 100 seeds is needed to establish one adult plant postfire [16] and for Pinus halepensis, it could produce the recruitment of 50000 to 200000 seedlings $\mathrm{ha}^{-1}$ in the post-fire seed bank when canopy storage is released and not enhanced by high temperatures $[33,41]$. Comparing results obtained in our study sites to those mentioned above, canopy seed bank was highly developed and large enough to ensure regeneration just 10 years after fire, only if other limiting factors are available, such as soft rains in the first autumn and/or winter, nutrient availability in soil, etc. The high serotiny of young populations like those studied here must ensure a large canopy seed bank, as the soil seed bank is vulnerable to predators and shortlived [38].
In conclusion, low densities help reproductive maturation and improve the health of young pine stands and can increase cone production. Even so, in ten year-old Aleppo pine stands, canopy-stored seed bank is larger in the highest-density sites. Furthermore, the number of stored seeds is equal to or greater than those obtained in similarly aged populations throughout the Mediterranean Basin.

Site quality is related to viability percentages, decreasing in semi-arid conditions which could thereby affect post-fire regeneration. Thus, research on silvicultural treatments, especially thinning, may be developed to estimate the optimal tree density for obtaining a healthy forest and preparing it for a new fire. Also, the stand age should be included in research to find the balance between high tree density stands with low individual cone yield versus low tree density stands with high individual viable seed production, stored as a larger canopy seed bank. Therefore, a drastic reduction in density (e.g. by thinning) in poor site quality areas have to be better studied before carrying out this technique because it could be unadvisable.

Acknowledgements: We wish to thank the Regional Forestry Services of Castilla-La Mancha, Murcia and Catalunya for providing the research sites and field collaborators. This research was funded by the R+D+I Spanish National Programme (AGL2004-07506/FOR). Also we would thank Stefanie A. Kroll (SUNY-ESF, New York) for assistant and language revision.

\section{REFERENCES}

[1] Abbas H., Barbéro M., Loisel R., Réflexions sur le dynamisme actuel de la régéneration naturelle du pin d'Alep (Pinus halepensis Mill.) dans les pinèdes incendiéés en Provence calcaire (de 1973 à 1979), Ecologia Mediterranea 10 (1984) 85-104.

[2] Agee J.K., Fire and pine ecosystems, in: Richardson D.M. (Ed.), Ecology and biogeography of Pinus, Cambridge University Press, Cambridge, 1988, pp. 193-218.

[3] Allen H.L., Gillespie A.R., Leaf area variation in mid rotation loblolly pine plantations, North Carolina State Forest Nutrition Cooperation, Res. Note No. 6, NC State University, Raleigh, 1991.

[4] Barbero M., Bonin G., Loisel R., Miglioretti F., Quèzel P. Incidence of exogenous factors on the regeneration of Pinus halepensis after fires, Ecología Mediterránea 13 (1987) 51-56.

[5] Broncano M.J., Riba M., Retana, J., Seed germination and seedling performance of two Mediterranean tree species, holm oak (Quercus ilex L.) and Aleppo pine (Pinus halepensis Mill.): a multifactor experimental approach, Plant Ecol. 138 (1998) 17-26.

[6] Broncano M.J., Retana J., Rodrigo A., Predicting the recovery of Pinus halepensis and Quercus ilex forests after a large wildfire in northeastern Spain, Plant Ecol. 180 (2005) 47-56.

[7] Bond W.J., Wilgen B.W., Fire and Plants, Usher, M.B., DeAngelis D.L., Manly B.F.J. (Eds), Chapman \& Hall, London, 1996.

[8] Calamassi R., Effetti della luce e della temperatura sulla gterminazione dei semi provenienze di Pinus halepensis mill e Pinus brutia Ten, Lítalia forestale e montana 4 (1982) 175-187.

[9] Calamassi R., Paoletti E., Seed germination of Pinus halepensis provenances under $\mathrm{NaCl}$ stress, Isr. J. Plant Sci. 52 (2004) 143-148.

[10] Corona P., Leone V., Saracino A., Plot size and shape for the early assessment of post-fire regeneration in Aleppo pine Stands, New For. 16 (1998) 213-220. 
[11] Cottrell H.J., Tetrazolium salt as a seed germination indicator, Nature 159 (748, 1947) 41-46.

[12] Daskalakou E.N., Thanos C.A., Aleppo pine (Pinus halepensis) postfire regeneration: The role of canopy and soil seed banks, Int. J. Wildland Fire 62 (1996) 59-66.

[13] De las Heras J., Gonzalez-Ochoa A., Lopez-Serrano F., Simarro M.E., Effects of silviculture treatments on vegetation after fire in Pinus halepensis Mill. woodlands (SE Spain), Ann. For. Sci. 61 (2004) 661-667.

[14] De las Heras J., Bonilla M., Martinez L.W., Germination after heat treatments of Pinus tropicalis Morelet and Pinus caribaea Morelet var. caribaea seeds of west Cuban forests, Ann. For. Sci. 63 (2006) 469-475.

[15] De las Heras J., Moya D., Lopez-Serrano F.R., Condes S., Reproduction of postfire Pinus halepensis Mill. stands six years after silvicultural treatments, Ann. For. Sci. 64 (2007) 59-66.

[16] Enright N.J., Lamont B.B., Marsula R., Canopy seed bank dynamics and optimum fire regime for the highly serotinous shrub Banksia hookeriana, J. Ecol. 84 (1996) 9-17.

[17] Escudero A., Perez-García F., Luzuriaga A.L., Effects of light, temperature and population variability on the germination of seven Spanish pines, Seed Sci. Res. 12 (2002) 261-271.

[18] Falusi M., Calamassi R., Tocci A., Sensitivity of seed-germination and seedling root-growth to moisture stress in 4 provenances of Pinus halepensis Mill., Silvae Genet. 32 (1983) 4-9.

[19] Gandullo J.M., Ecología de los pinares españoles. III. Pinus halepensis Mill., Ministerio de Agricultura, Instituto Nacional de Investigaciones Agrarias, Madrid, 1972.

[20] González-Ochoa A.I., de las Heras J., Tores P., Sánchez-Gómez E., Mycorrhization of Pinus halepensis Mill. and Pinus pinaster Aiton seedlings in two commercial nurseries, Ann. For. Sci. 60 (2003) 43-48.

[21] González-Ochoa A.I., López-Serrano F.R., de las Heras J., Does post-fire forest management increase tree growth and cone production in Pinus halepensis? For. Ecol. Manage. 188 (2004) 235-247.

[22] Gonzalez J.R., Pukkala T., Palia M., Optimising the management of Pinus sylvestris L. stand under risk of fire in Catalonia (north-east of Spain), Ann. For. Sci. 62 (2005) 493-501.

[23] Goubitz S., Werger M., Ne'eman G., Germination response to firerelated factors of seeds from non-serotinous and serotinous cones, Plant Ecol. 169 (2003) 195-204.

[24] Goubitz S., Nathan R., Roitemberg R., Shmida A., Ne'eman G., Canopy seed bank structure in relation to: fire, tree size and density, Plant Ecol. 173 (2004) 191-201.

[25] Henig-Sever N., Eshel A., Ne'eman G., Regulation of the germination of Aleppo pine (Pinus halepensis) by nitrate, ammonium, and gibberellin, and its role in post-fire forest regeneration, Physiol. Plant. 108 (2000) 390-397.

[26] Keeley J.E., Zedler P.H., Evolution of life histories in Pinus, in: Richardson D.M. (Ed.), Ecology and biogeography of Pinus, Cambridge University Press, Cambridge, 1998, pp. 219-251.

[27] Mouillot F., Ratte J.P., Joffre R., Mouillot D., Rambal S., Longterm forest dynamic after land abandonment in a fire prone Mediterranean landscape (central Corsica, France), Landscape Ecol. 20 (2005) 101-112.

[28] Nathan R., Ne'eman G., Serotiny, seed dispersal and seed predation in Pinus halepensis, in: Ne'eman G., Trabaud L. (Eds.), Ecology, biogeography and management of Pinus halepensis and P. brutia forest ecosystems in the Mediterranean Basin, Backhuys publishers, Leiden, 2000, pp. 105-118.

[29] Nathan R., Ne'eman G., Spatiotemporal dynamics of recruitment in Aleppo pine (Pinus halepensis Miller), Plant Ecol. 171 (2004) 123-137.

[30] Naveh Z., The role of fire and its management in the conservation of Mediterranean ecosystems and landscapes, in: Moreno J.M.,
Oechel W.C. (Eds.), The role of fire in Mediterranean type ecosystems, Springer-Verlag, New York, 1994, pp. 163-186.

[31] Ne'eman G., Lahav H., Izhaki I., Spatial pattern of seedlings 1 year after fire in a Mediterranean pine forest, Oecologia 91 (1992) 365370.

[32] Ne'eman G., Izhaki I., Stability of pre- and post-fire spatial structure of pine trees in Aleppo pine forest, Ecography 21 (1998) 535-542.

[33] Ne'eman G., Goubitz S., Nathan R., Reproductive traits of Pinus halepensis in the light of fire - a critical review, Plant Ecol. 171 (2004) 69-79.

[34] Pausas J.G., Gimeno T., Vallejo R., Fire severity and pine regeneration in the Eastern Iberian Peninsula, in: Viegas D. (Ed.), Forest field research and wildland fire safety, Millpress, Rotterdam, 2002, pp. 580-587.

[35] Quezel P., Taxonomy and biogeography of Mediterranean pines (Pinus halepensis and P. brutia), in: Ne'eman G., Trabaud L. (Eds.), Ecology, biogeography and management of Pinus halepensis and $P$. brutia forest ecosystems in the Mediterranean basin, Backhuys publishers, Leiden, 2000, pp. 1-12.

[36] Rivas-Martinez S., Pisos bioclimaticos de España, Lazaroa 5 (1983) $33-43$.

[37] Reyes O., Casal M., Seed germination of Quercus robur, Q. pyrenaica and $Q$. ilex and the effects of smoke, heat, ash and charcoal, Ann. For. Sci. 63 (2006) 205-212.

[38] Saracino A., D’Alessandro C.M., Borghetti M., Seed colour and post-fire bird predation in a Mediterranean pine forest, Acta Oecol. 26 (2004) 191-196.

[39] Shoennagel T., Turner M., Romme W., The influence of fire interval and serotiny on postfire lodgepole pine density in Yellowstone National Park, Ecology 84 (2003) 2967-2978.

[40] Smida A., Lev-Yadun S., Goubitz S., Neeman G., Sexual Allocation and gender segregation in Pinus halepensis, P. brutia and P. pinea, in: Ne'eman G., Trabaud L. (Eds.), Ecology, biogeography and management of Pinus halepensis and P. brutia forest ecosystems in the Mediterranean basin, Backhuys publishers, Leiden, 2000, pp. 91-104.

[41] Tapias R., Gil L., Fuentes-Utrilla, Pardos J.A., Canopy seed banks in Mediterranean pines of south-eastern Spain: a comparison between Pinus halepensis Mill., P. pinaster Ait., P. nigra Arn. and $P$. pinea L., J. Ecol. 89 (2001) 629-638.

[42] Tapias R., Climent J., Pardos J.A., Gil L., Life histories of Mediterranean pines, Plant Ecol. 171 (2004) 53-68.

[43] Thanos C.A., Ecophysiology of seed germination in Pinus halepensis and P. brutia, in: Ne'eman G., Trabaud L. (Eds.), Ecology, biogeography and management of Pinus halepensis and P. brutia forest ecosystems in the Mediterranean basin, Backhuys Publishers, Leiden, 2000, pp. 37-50.

[44] Thanos C.A., Daskalakou E.N., Reproduction in Pinus halepensis and P. brutia, in: Ne'eman G., Trabaud L. (Eds.), Ecology, biogeography and management of Pinus halepensis and P. brutia forest ecosystems in the Mediterranean basin, Bakhuys Publishers, Leiden, 2000, pp. 79-90.

[45] Tonon G., Panzacchi P., Grassi G., Gianfranco M., Cantoni L., Bagnaresi U., Spatial dynamics of late successional species under Pinus nigra stands in the northern Apennines (Italy), Ann. For. Sci. 62 (2005) 669.

[46] Trabaud L., Michels C., Grossman J., The recovery of burned Pinus halepensis Mill. forests. II Pine reconstitution after wild-fire, For. Ecol. Manage. 13 (1985) 167-179.

[47] Verkaik I., Espelta J.M., Post-fire regeneration thinning, cone production, serotiny and regeneration age in Pinus halepensis, For. Ecol. Manage. 231 (2006) 155-163. 